\title{
Osteochondromas originating from unusual locations complicating orthopedic discipline: case series
}

\author{
Ortopedi disiplininde sorun yaratan sıra dışı yerleşim kaynaklı osteokondromlar: Olgu serisi
}

\author{
Kemal Gökkuş, MD., ${ }^{1}$ Halil Atmaca, MD., ${ }^{2}$ Ergin Sağtaş, MD, ${ }^{3}$ Murat Saylık, MD., ${ }^{4}$ Ahmet Turan Aydın, MD. \\ ${ }^{1}$ Department of Orthopedics and Traumatology, Antalya Memorial Hospital, Antalya, Turkey \\ ${ }^{2}$ Department of Orthopedics and Traumatology, Medical Faculty of Akdeniz University, Antalya, Turkey \\ ${ }^{3}$ Department of Radiodiagnostic, Antalya Memorial Hospital, Antalya, Turkey \\ ${ }^{4}$ Department of Orthopedics and Traumatology, Özel Bahar Hospital, Bursa, Turkey
}

\begin{abstract}
Herein, we report clinical, radiological, and follow-up results of seven cases of extraordinary located osteochondromas and highlight the importance of rare and unusual properties of unusual locations of osteochondromas. Seven patients with extraordinary located osteochondromas were treated in our institution (Antalya Memorial Hospital) between the period of February 2009 and March 2014 were reported. The patients were classified according to the localization, symptomatology, and the presence of neurovascular involvement or organ compression. The results were discussed with the existing literature data. Five of our patients had unusual symptomatology. Surgical excision was performed on six of seven patients. One patient was followed with scheduled outpatient visits alone. Our clinical followup results were good to excellent. In our case series, one patient with clavicular involvement had impaired shoulder mechanic which resulted in painful shoulder, while another with pubic ramus involvement had obstructive urination symptoms and dysuria. One patient with scapular involvement had snapping scapula symptoms, while two patients with fibular head involvement had peroneal nerve compression and tibial nerve compression symptoms in each. One patient with ischial ramus involvement had sciatica, whereas another with first rib involvement had radiological evidences for subclavian artery compression due to osteochondroma without any symptom. Based our experience, the flat bones which are usually ossified by intramembranous type of ossification during the fetal period (including the scapula, ilium, pubic ramus, ischium ramus, ribs and clavicle) are much less commonly affected and often have unusual symptoms. The osteochondromas originating from the fibular head may seem innocent to an orthopedic surgeon. However, an orthopedic surgeon should be alert to tibiofibular synostosis and nerve compression in this patient population.

Keywords: Bone tissue; cartilage; excision; neoplasm; osteochondroma.
\end{abstract}

öz

Amaç: $\mathrm{Bu}$ yazıda, sıra dışı yerleşimli osteokondromlu yedi olgunun klinik, radyolojik ve takip sonuçları bildirildi ve bu sıra dışı yerleşimli osteokondromların nadir ve sıra dışı özelliklerinin önemi vurgulandı. Şubat 2009 - Mart 2014 tarihleri arasında kliniğimizde (Antalya Memorial Hastanesi) tedavi edilen sıra dışı yerleşimli yedi osteokondromlu hasta bildirildi. Hastalar yerleşim yerlerine, bulgularına ve nörovasküler tutulum veya organ basısı varlığına göre sınıflandırıldı. Sonuçlar, mevcut literatür verileri eşliğinde tartışıldı. Hastalarımızın beşinde sıra dışı semptomatoloji vardı. Yedi hastanın altısına cerrahi eksizyon yapıldı. Bir hasta yalnızca planlı poliklinik viziti ile takip edildi. Klinik sonuçlarımız iyi ila mükemmeldi. Olgu serimizde, klavikula tutulumlu bir hastada omuz mekaniğinin bozulmasına bağlı omuz ağrısı; pubik tutulumlu bir diğerinde tıkalı idrar yolu bulguları ve dizüri vardı. Skapula tutulumlu bir hastada yalancı kanat skapula semptomları; fibula başı tutulumlu iki hastanın birinde peroneal sinir sıkışması ve diğerinde tibial sinir sıkışması semptomları vardı. İskiyal ramus tutulumlu bir hastada siyatalji; kaburga tutulumlu bir diğerinde ise herhangi bir semptom olmaksızın osteokondroma bağlı subklavyen arter basısının radyolojik bulguları vardı. Deneyimlerimize göre, fetal dönemde genellikle intramembranöz tipi kemikleşme yoluyla oluşan yassı kemikler (skapula, iliyum, pubik ramus, iskiyum ramus, kaburgalar ve klavikula dahil olmak üzere) nadiren çok daha az etkilenir ve sıklıkla sıra dışı semptomlar ile birlikte seyreder. Fibula başı kaynaklı osteokondromlar, ortopedi cerrahlarına masum görünebilir. Ancak, ortopedi cerrahlari bu hasta grubunda tibiofibular sinositoz ve sinir basısına karşı uyanık olmalıdır.

Anahtar sözcükler: Kemik doku; kıkırdak; eksizyon; neoplazma; osteokondrom.

\footnotetext{
- Received: February 11, 2015 Accepted: May 07, 2015
}

- Correspondence: Kemal Gökkuş, M.D. Memorial Antalya Hastanesi, Ortopedi ve Travmatoloji Bölümü, 07020 Kepez, Antalya, Turkey. Tel: +90 242 - 3146666 / 4131 Fax: +90 242 - 3441678 e-mail: kgokkus@gmail.com 
Osteochondromas, the most common benign bone lesions (accounting for about $45 \%$ of all benign bone tumors and $12 \%$ of all bone tumors) is a cartilagecapped bony projection on the external surface of a bone. ${ }^{[1]}$ Usually diagnosed before the third decade, it most commonly involves the metaphyses of the long bones, in particular, around the knee and the proximal humerus. ${ }^{[2,3]}$

An osteochondroma is a hamartoma derived from an aberrant subperiosteal germ of the physeal cartilage, which grows and matures depending on normal enchondral ossification. ${ }^{[4,5]}$ Although it occurs in early infancy, the exostosis is usually first noticed between 6 to 20 years of age..$^{[2]}$

In general, lower extremities are more often affected than the upper extremities. The flat bones which are usually ossified by intramembranous type of ossification during the fetal period (including the scapula, ilium, pubic ramus, ischium ramus, ribs, and clavicle) are much less commonly affected. ${ }^{[5]}$ In this article, we report clinical, radiological, and follow-up results of seven cases of extraordinary located osteochondromas who were treated in our clinic and highlight the importance of rare and unusual properties.

Between February 2009 and March 2014, seven patients with extraordinary located osteochondromas (originating from the bones which were evolved from the intramembranous type of ossification during the fetal life including the scapula, pubic ramus, ischium ramus, ribs and clavicle in five patients; head of the fibula located which were evolved with enchondral ossification bone in two patients) were reported. The case distribution is shown in the whole skeleton scheme in Figure 1. The patients were classified according to the localization, symptomatology, and the presence of neurovascular involvement or organ compression. The results were discussed with the existing literature data (from the scope of unexpected symptomatology) with these rarely seen case series of unusual locations (Table 1). All patients or family members were informed that their data would be submitted for publication. Informed consents were obtained and were archived in the patients record system.

\section{CASE REPORTS}

Case 1- A 20-year-old female patient presented with right groin pain, dysuria and obstructive urination symptoms. Physical examination showed a bony lump arising from the right pubic ramus. She was originally misdiagnosed with urological disorder, namely cystitis, and was followed at another outpatient clinic. Plain radiographs showed a large osseous mass originating from the pubic ramus towards the obturator foramen (Figure 2). Computed tomography (CT) scans demonstrated stalk-like osseous protuberance originating from the posterior surface of the (ischia-pubic ramus) inferior pubic ramus (Figure 2) and the mass was located adjacent to the bladder neck. We utilized the technique of Radley's approach for inferior pubic ramus and resected inferior pubic ramus with the bony mass.

Urinary symptoms were relieved following surgery and the patient was totally pain-free one month after surgery. Histopathological examination findings were consistent with an osteochondroma.

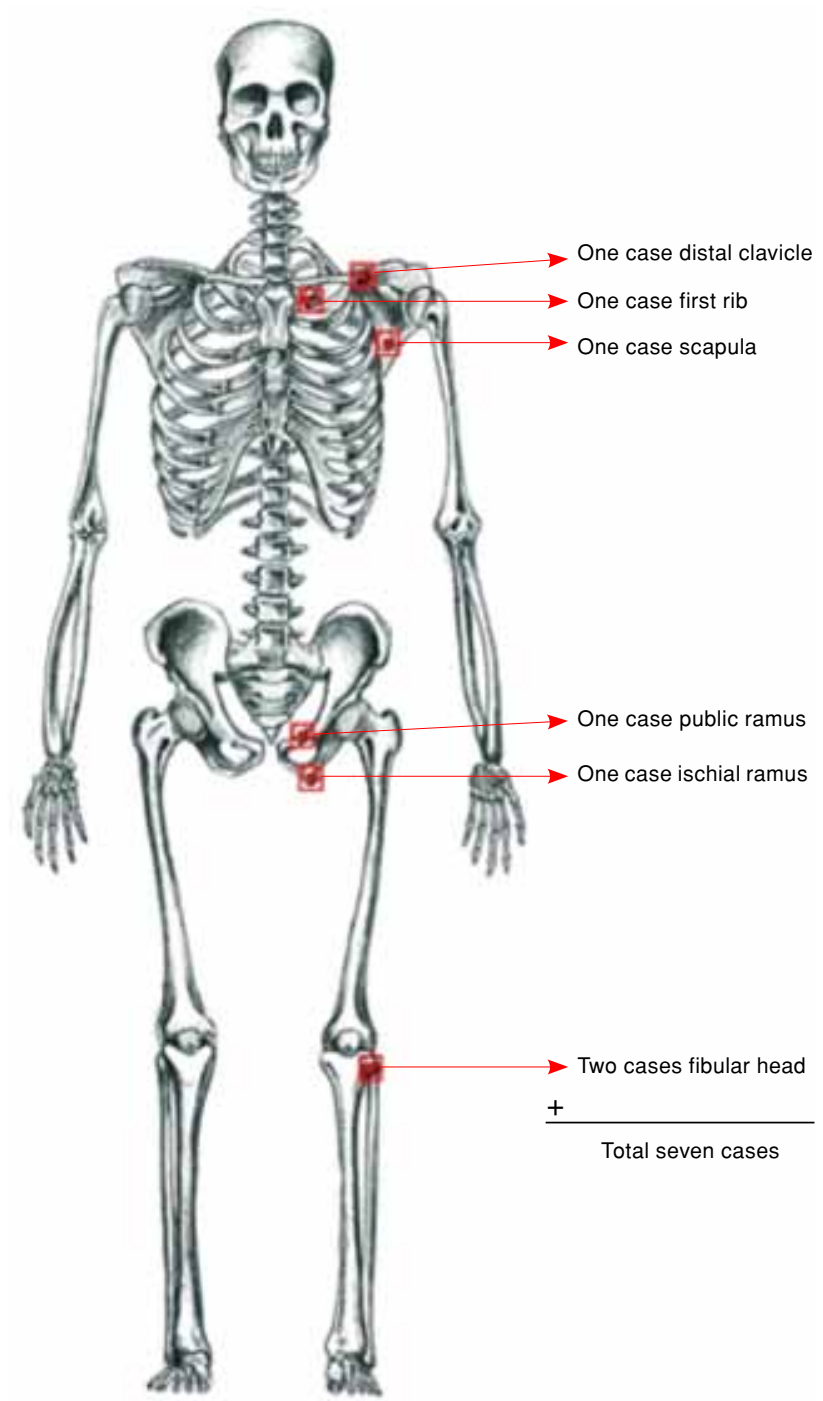

Figure 1. Whole skeleton scheme including the distribution of our cases. 
TABLE I

Cases according to anatomic location, symptomatology, nerve compression, vascular compression and organ compression. Third and four columns emphasizes the rarity of our case series. Last column shows the clinical result

\begin{tabular}{|c|c|c|c|c|c|c|c|c|}
\hline & $\begin{array}{l}\text { Anatomical } \\
\text { location }\end{array}$ & $\begin{array}{c}\text { Unusual } \\
\text { symptomatology }\end{array}$ & $\begin{array}{l}\text { Rarity } \\
\text { according } \\
\text { to Rizzoli } \\
\text { institution } \\
\text { statistics }\end{array}$ & $\begin{array}{l}\text { Rarity } \\
\text { according to } \\
\text { literature }\end{array}$ & $\begin{array}{c}\text { Nerve } \\
\text { compression }\end{array}$ & $\begin{array}{c}\text { Vascular } \\
\text { compression }\end{array}$ & $\begin{array}{c}\text { Organ } \\
\text { compression }\end{array}$ & $\begin{array}{l}\text { Treatment and } \\
\text { clinical result }\end{array}$ \\
\hline Case 1 & Symphisis pubis & $\begin{array}{c}\text { +(Groin pain, } \\
\text { obstructive } \\
\text { urination } \\
\text { symptoms and } \\
\text { dysuria) }\end{array}$ & $\begin{array}{c}7 \text { cases } \\
\text { in } 1954 \\
(0.00358 \%)\end{array}$ & $\begin{array}{l}7 \text { articles in } \\
\text { literature }{ }^{[13-19]}\end{array}$ & - & - & $\begin{array}{c}+(\text { Bladder } \\
\text { neck })\end{array}$ & $\begin{array}{l}\text { Excision- } \\
\text { excellent }\end{array}$ \\
\hline Case 2 & $\begin{array}{c}\text { Ventral side } \\
\text { scapula }\end{array}$ & $\begin{array}{c}+ \text { (Winging and } \\
\text { snapping) }\end{array}$ & $\begin{array}{c}136 \text { cases } \\
\text { in } 1954 \\
(0.069 \%)\end{array}$ & $\begin{array}{l}15 \text { articles } \\
\text { (except } \\
\text { surgical } \\
\text { technique } \\
\text { reports) }{ }^{[41-55]}\end{array}$ & - & - & - & $\begin{array}{l}\text { Excision- } \\
\text { excellent }\end{array}$ \\
\hline Case 3 & Proximal fibula & $\begin{array}{c}+(\text { Leg pain, } \\
\text { paresthesia) }\end{array}$ & $\begin{array}{c}52 \text { cases } \\
\text { in } 1954 \\
(0.0266 \%)\end{array}$ & $\begin{array}{l}14 \text { articles in } \\
\text { literature }{ }^{[20-33]}\end{array}$ & $+($ Peroneal ) & - & - & $\begin{array}{l}\text { Excision- } \\
\text { excellent }\end{array}$ \\
\hline Case 4 & Proximal fibula & $\begin{array}{c}+(\text { Post tibial } \\
\text { nerve entrapment } \\
\text { symptomatology) }\end{array}$ & $\begin{array}{c}52 \text { cases } \\
\text { in } 1954 \\
(0.0266 \%)\end{array}$ & $\begin{array}{l}14 \text { articles in } \\
\text { literature }\end{array}$ & $+($ Tibial nerve $)$ & - & - & $\begin{array}{l}\text { Excision- } \\
\text { excellent }\end{array}$ \\
\hline Case 5 & First rib & $\begin{array}{c}\text { +(Presented as } \\
\text { a supraclavicular } \\
\text { lymphadenopathy) }\end{array}$ & $\begin{array}{l}14 \text { cases } \\
\text { in } 1954 \\
(0.007 \%)\end{array}$ & $\begin{array}{l}6 \text { articles in } \\
\text { literature }\end{array}$ & - & $\begin{array}{l}+(\text { Arterial } \\
\text { compression } \\
\text { was proved } \\
\text { radiologically } \\
\text { but patient } \\
\text { had no clinical } \\
\text { symptoms) }\end{array}$ & $\begin{array}{l}- \\
- \\
-\end{array}$ & $\begin{array}{l}\text { Observation, } \\
\text { the patient } \\
\text { leads } \\
\text { normal life }\end{array}$ \\
\hline Case 6 & Ischial ramus & $\begin{array}{c}+(\text { Presented } \\
\text { as L4-L5-S1) } \\
\text { radiculopathy) }\end{array}$ & $\begin{array}{c}4 \text { cases } \\
\text { in } 1954 \\
(0.002 \%)\end{array}$ & $\begin{array}{l}1 \text { article in } \\
\text { literature }^{[5]}\end{array}$ & $\begin{array}{c}+(\text { Sciatic } \\
\text { nerve) }\end{array}$ & - & & $\begin{array}{l}\text { Excision- } \\
\text { excellent }\end{array}$ \\
\hline Case 7 & Distal clavicle & $\begin{array}{l}+ \text { (Presented as } \\
\text { painful shoulder })\end{array}$ & $\begin{array}{l}4 \text { cases } \\
\text { in } 1954 \\
(0.002 \%)\end{array}$ & $\begin{array}{l}6 \text { articles in } \\
\text { literature }{ }^{[35-40]}\end{array}$ & - & - & & $\begin{array}{l}\text { Excision- } \\
\text { excellent }\end{array}$ \\
\hline
\end{tabular}

Case 2- A 21-year-old female patient presented with shoulder pain. Physical examination revealed a bony mass at the anterior aspect of shoulder located between the subclavicular area and the coracoid process. This area was very sensitive to palpation. Plain radiographs showed a large cauliflower-like osseous mass projecting from the $1 / 3$ mid-clavicle (at the border of the distal 1/3 part of clavicle) towards the coracoid process. Computed tomography scans demonstrated stalk-like osseous protuberance originating from the inferior surface of the clavicular mid-shaft. The mass pressurized the coracoid (Figure 3).

Surgery was performed to decompress the gap between the subclavicular and coracoid empty space. The base of the excised tumor was very similar to a saddle. The coracoid process was also deformed with the long-time pressure of the osseous mass (Figure 3). One month after the surgery, the shoulder was painfree. Histopathological examination findings were consistent with an osteochondroma.
Case 3- A six-year-old boy presented with pain and swelling of the anterolateral aspect of the right proximal leg. There was no antecedent trauma and fever. During clinical examination, a moderate swelling was seen over the anterolateral aspect of the right proximal leg, which was approximately $5 \times 3 \times 3 \mathrm{~cm}$ in size.

There was no restricted movement in knee joint and there was no neurovascular deficit in the extremity. Plain radiographs (anteroposterior and lateral view) of the leg with knee revealed a large cauliflower-like growth arising from proximal fibula (Figure 4). Computed tomography scans demonstrated stalk-like osseous protuberance originating from the fibular head and growing mostly into the popliteal fossa instead of lateral side (Figure 4).

A linear incision was taken posteriorly of the fibula along the line of biceps femoris tendon. Following superficial surgical dissection, common 

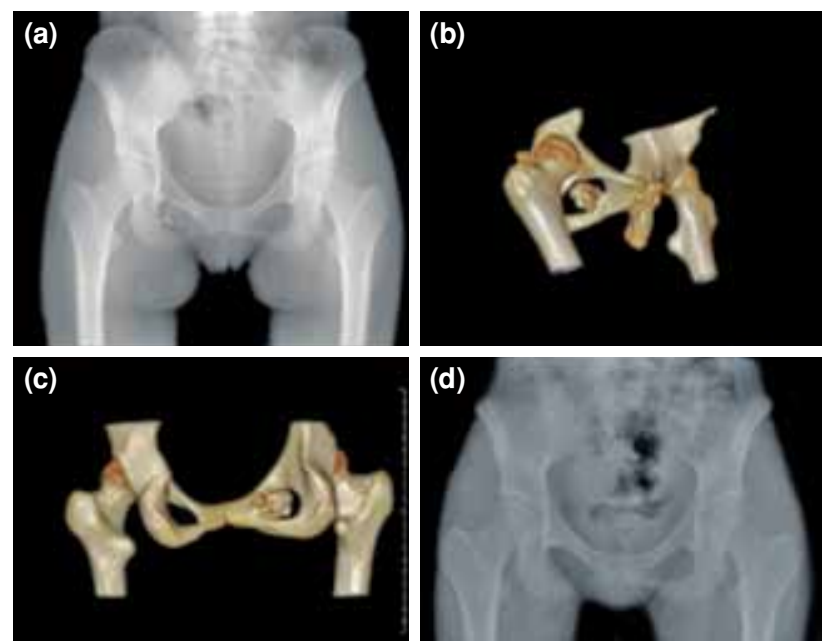

Figure 2. (a) Plain radiography showing the right obturator foramen fulfilled with large cauliflower-like osseous mass. (b, c) Anterior and posterior view of the mass with three dimensionalcomputed tomography. (d) Postoperative X-ray.

peroneal nerve was isolated and preserved. Muscles were stripped and fibula was exposed. En-bloc excision of tumor was performed. At two months following surgery, the knee and proximal leg were pain-free. Histopathological examination findings were consistent with an osteochondroma.

Case 4- A 40-year-old female patient was admitted to our clinic with left back scapular pain and protrusion in that area. The pain was present for five years. Physical examination revealed limited and painful left shoulder movements, in scapula-thoracic component and pseudo-winging, particularly. The preoperative constant score was 36 . Plain radiographs (anteroposterior and lateral view) of scapula revealed a large cauliflower-like growth arising from the ventral side of scapula (Figure 5). Computed tomography scans demonstrated stalklike osseous protuberance originating from the ventral side of scapula (Figure 5).

Surgical resection of the exostosis was performed through a medial approach (Figure 5). Histopathological examination confirmed the diagnosis of an osteochondroma. Two months after surgery, the left shoulder was pain-free. The constant score increased to 76 during one-year follow-up.

Case 5- A 71-year-old male patient was admitted to gastroenterology outpatient clinic with abdominal pain, meteorism, nausea, and vomiting. Based on physical examination and laboratory test results, the patient was diagnosed with cholangitis due to gallstones. On physical examination, the gastroenterologist noticed a right supraclavicular lymph node-like mass on the supraclavicular area. Plain radiographs (anteroposterior) of the chest revealed a small stalk-like bony mass growth arising from the anterior side of right first rib (Figure 6). Computed tomography scans demonstrated stalklike osseous protuberance originating from the right first rib (Figure 6). Since the patient had no lesionrelated complaints or functional impairment, surgery was not required. Outpatient follow-up visits were scheduled. The radiological features of this bony protuberance suggested an osteochondroma.

Case 6- A 25-year-old male patient was admitted with a 10-year radiating pain and sciatalgia in the right lower extremity. The pain worsened in the
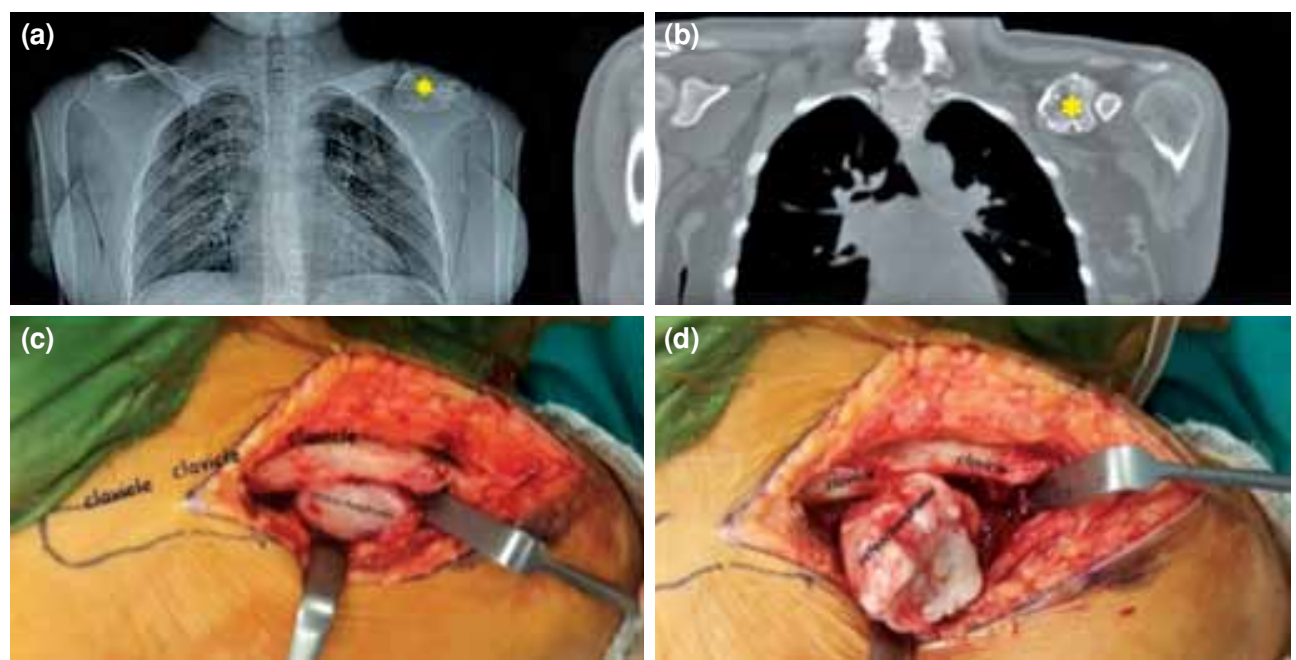

Figure 3. (a, b) Plain radiography and computed tomography scan, asterisk shows the cauliflowerlike osseous mass originating from distal clavicle and sits on the coracoid. (c, d) Intraoperative photo, notice the shape of osteochondroma which was changed with pressure over time. 

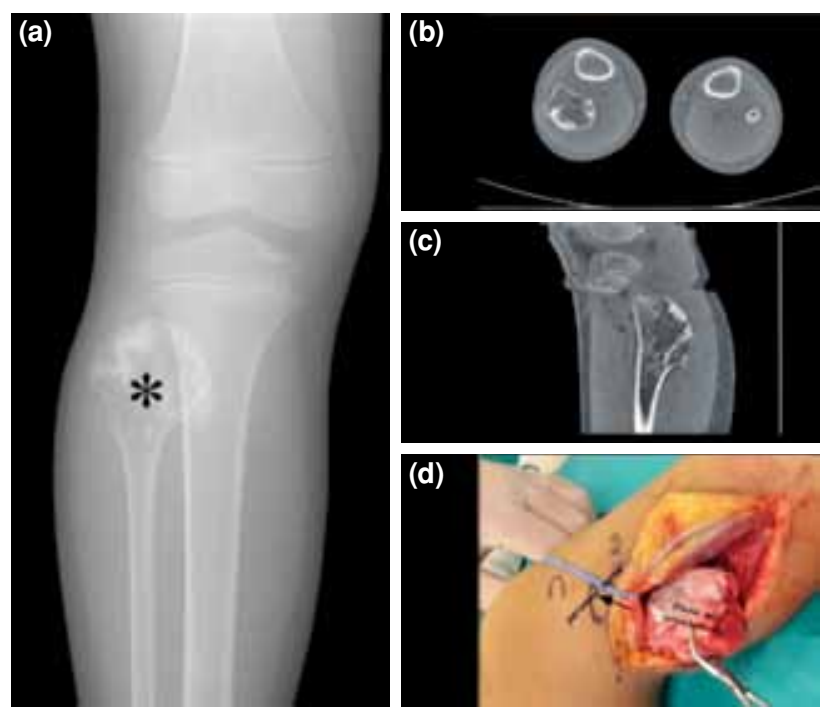

Figure 4. (a) Plain radiography asterisk shows the osteochondroma originating from fibular head. $(\mathbf{b}, \mathbf{c})$ Computed tomography scans show the cauliflower-like osseous mass. (d) Intraoperative photo shows how the lesion was adjacent to the peroneal nerve.

sitting position. Non-steroidal anti-inflammatory drugs provided minimal pain relief. On physical examination, the patient was healthy-looking, although there was limping on the right side. There was also tenderness around the ischial tuberosity. The right side hip flexion contracture (5 to 10 degrees) was detected without limited hip rotational motions. The Faber test produced positive results. The Lasegue test was positive at 60 to 70 degrees angle on the right side and a painful resisted flexion of the hip was detected. Neurological examination revealed that the patient had radiating pain and paresthesia at the ipsilateral
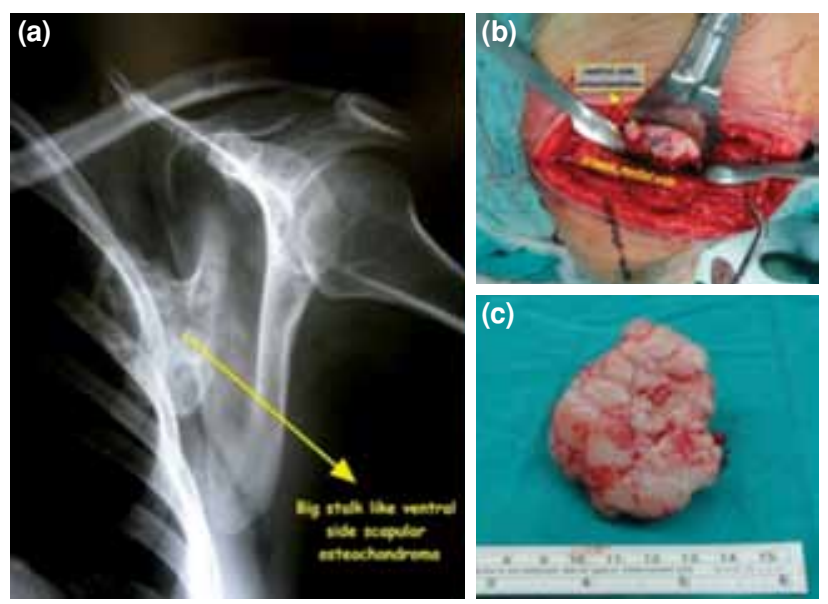

Figure 5. (a) Plain radiography shows the big stalk like scapularventral side located osteochondroma. (b) Intraoperative photo shows patient position and incision. (c) Excised tumor.

lower extremity and also weakness at the plantar flexion of the foot. Plain radiography and CT scans revealed an exostotic projection composed of dense calcification of the cartilaginous cap from the right ischial ramus (Figure 7). On the CT scans, one can see that in comparison with the normal side (arrow 1); the sciatic nerve on the affected side (arrow 2) is pushed from the femoroischial line (Figure 7).

En bloc excision was performed through the modified Gibson incision in which the curved part of the incision was lowered to approach the ischial tuberosity.

Postoperatively, the patient's radiating pain and paresthesia completely resolved and neurological
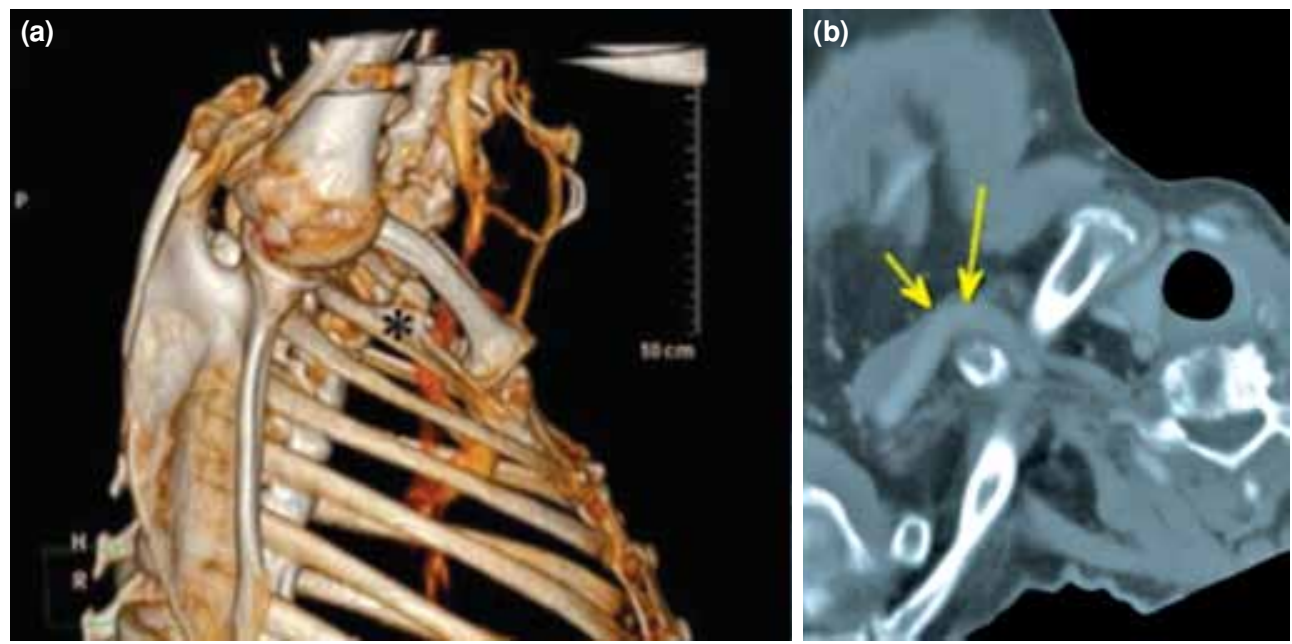

Figure 6. (a) Three dimensional-computed tomography scan, asterisk shows stalk like bony mass. (b) Computed tomography scan, arrows show the subclavian artery was compressed by osteochondroma. 

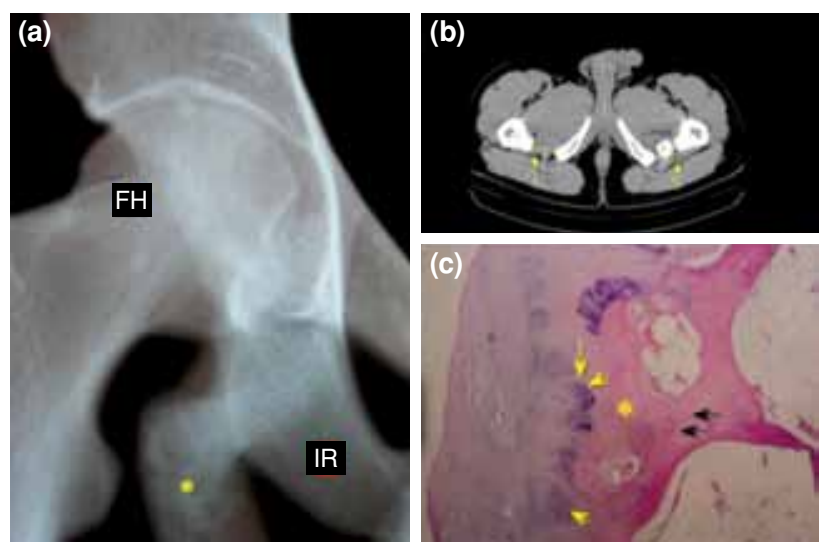

Figure 7. (a) Plain radiography, asterisk shows the stalklike bony mass. (b) Computed tomography scan, second yellow arrow shows the sciatic nerve which was pushed by osteochondroma. (c) Histological preparation of a synovial solitary osteochondroma $(H-E \times 4)$ revealed the characteristic pattern of an osteochondroma which is covered by a thick cartilaginous cap formed with columnar arrangement of chondrocytes (black arrows) which is typical for osteochondroma. At the chondroosseous junction, osteoid matrix (asterisk) with osteocytes (yellow arrows) forming bony trabecula is apparent at the base of the cap. IR: Represents the ischial ramus; FH: Represents the femoral head.

symptoms were improved. Subsequent pathology reports showed an osteochondroma without any evidence of malignancy (Figure 7).

This case is the one of our collection which has been published previously by the authors of this study as a case report in the Joint Diseases \& Related Surgery. ${ }^{[5]}$

Case 7- An 18-year-old female patient was admitted to the orthopedics outpatient clinic with a swollen and painful mass behind her left knee and proximal leg. She had this mass for four years without any tenderness or neurovascular complaints. The main complaints were only aesthetic concerns. Physical examination revealed an approximately $5 \times 7 \mathrm{~mm}$ immobile solid mass behind the knee joint, starting from proximal fibula. Palpation showed minimal tenderness around the mass. During clinical examination, there was no evidence of neurovascular compression. Plain radiographs showed a bony mass growth arising from proximal fibula to posteromedial aspect of tibia (Figure 8). The mass grew towards to the tibial side and established proximal tibiofibular synostosis (Figure 8). The dimension of excostic projection was $39 \times 52 \times 70 \mathrm{~mm}$, whereas the thickness of cartilaginous cap was $8 \mathrm{~mm}$ based on the magnetic resonance imaging findings. The cartilage side of the mass was in full contact with posterior
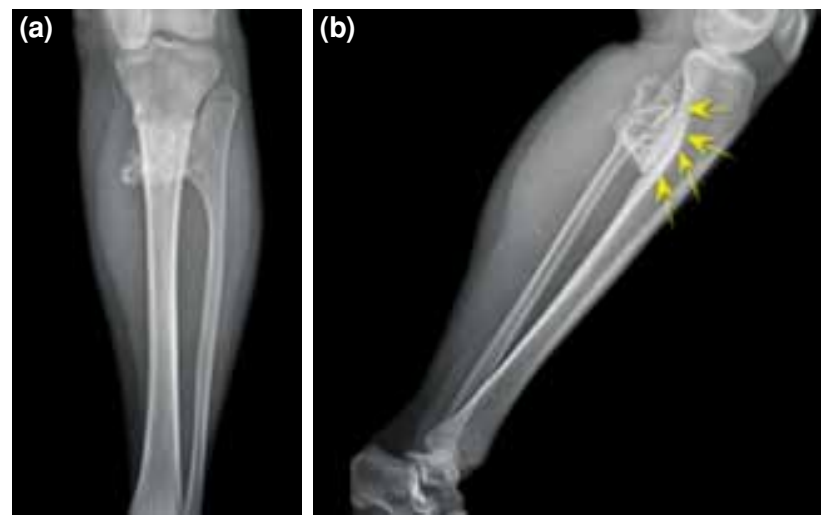

Figure 8. (a) Plain radiography shows the stalk-like bony mass originating from fibular head. (b) Yellow arrows show how the mass compressed the tibial cortex and caused to become thinner. Notice the proximal tibiofibular synostosis.

cortex of tibia (Figure 8). The patient was not operated and only scheduled for follow-up visits. During the follow-up period, she suffered from some complaints of paresthesia on the sensorial area of tibial nerve and she had an increased swelling of her left leg with grade 1 expansion in the veins. Electromyography (EMG) showed moderate compression on tibialis posterior nerve at the level of the mass. As the symptomatology worsened and tibial nerve compression symptoms initiated, a surgical intervention was considered.

The surgery was performed on prone position. A S-shaped incision was used to cross the flexion crease from distal medial femur to proximal fibula. Medial sural cutaneous nerve and small saphenous vein were identified and dissection was continued through to the neurovascular bundle and peroneal nerve. Then, common peroneal nerve and neurovascular bundle were isolated and protected. After neurovascular dissection, lateral gastrocnemius head was identified and retracted. Finally the lesion on the fibula leaning on the tibia was exposed.

The root of the lesion from proximal fibula was easily removed; however, the cartilaginous part was not clearly excised due to fusion to posterior aspect of proximal tibia (Figure 8). Pathological results revealed an osteochondroma. After surgery, the patient still suffered from paresthesia at the sensorial area of tibial nerve, although she was being followed for one year.

\section{DISCUSSION}

Minimum follow-up was one year in this study. All patients had unusual symptomatology and our clinical results were good to excellent. In our case 
series, the patients with clavicular involvement had impaired shoulder mechanic which resulted in painful shoulder, those with pubic ramus involvement had obstructive urination symptoms, those with scapular involvement had snapping scapula symptoms, and two patients with fibular head involvement had peroneal nerve and tibial nerve compression symptoms, consistent with the literature data. One patient with ischial ramus involvement case had sciatica. One with the first rib involvement had subclavian artery compression radiologically without compression symptoms, unlike previously reported study findings.

Regarding the originality and rarity of our case series, we performed a literature scan using the PubMed database. The following research criteria were applied: ${ }^{[1]}$ articles written in English, ${ }^{[2]}$ articles which we were able to be obtained as at least abstracts or full text, ${ }^{[3]}$ case reports involving the clavicular osteochondroma, fibular head osteochondroma, the first rib osteochondroma, pubic osteochondroma, ischial ramus osteochondroma, and scapular osteochondroma, ${ }^{[4]}$ and articles written in languages other than English but had descriptive titles or written abstracts in English which summarized the article.

Other articles on multiple hereditary exostosis, articles written in other than English without a descriptive title or an abstract on PubMed, articles on subacromial region of the scapula and articles concerning the surgical technique particular with scapular and fibular osteochondromas were excluded.

Recent literature has 2,965 articles on osteochondroma including multiple hereditary exostosis and surgical techniques. Only 49 of the 117 found articles fulfilled our inclusion criteria. Regarding the rarity of their locations, our case series in all articles' pool was $(0.0165 \%)$. We analyzed and discussed our cases in six different anatomical regions, comparing our results with the current literature.

According to the Rizzoli Institution statistical results obtained between 1900 and $2009,{ }^{[6]}$ out of 1,954 cases, only four were located at clavicle $(0.002 \%)$, four at ischial ramus $(0.002 \%)$, seven in pubic ramus $(0.00358 \%), 14$ in ribs $(0.007 \%), 52$ in fibular head $(0.026 \%)$, and 136 in scapula $(0.069 \%){ }^{[6]}$

According to these data, we suggest that the presentation of our seven cases will be extremely rare phenomena.
Based on the histological and experimental analysis on the formation of osteochondromas, it can be indicated that osteochondromas originate from a developmental defect of perichondrial ring (Ranvier ring), which surrounds the growth plate (physis). ${ }^{[7-10]}$ Growth plates exist in bones which are formed by enchondral ossification process during the fetal period. ${ }^{[11]}$

After fetal development of the process of bone, formation continues throughout growth. ${ }^{[10]}$ All bones of the body, except the flat bones of the skull, mandible, and clavicles are formed through the endochondral ossification. ${ }^{[7,8,10-12]}$

Therefore, osteochondromas usually evolve near the active growth plates adjacent to the metaphyseal region of the long bones (distal femur and proximal tibia). In this article, we present seven osteochondroma cases, which were ossified by intramembranous type of ossification during the fetal period (including the scapula, pubic ramus, ischium ramus, ribs, and clavicle). In general, these bones do not have growth plates. In the other two cases with fibular head involvement, the bones were ossified by enchondral type of ossification during the fetal period.

On the other hand, pelvic bone involvement is often rare. Unlike limb involvement, the symptomatology of pelvic involvement may present in an unusual course.

To the best of our knowledge, no case of osteochondroma clearly defined on ischial ramus developing sciatalgia was reported previously except one study described by Gökkuş et al. ${ }^{[5]}$

One patient with an ischial ramus located osteochondroma was overlooked for a long period, before he was admitted to our clinic. As the symptomatology suggested radiculopathy, previous treating physicians attempted to treat a non-existent L4-L5-S1 radiculopathy in this patient.

Furthermore, 12 out of 22 reported articles in the literature reporting pubic ramus involvement, only eight fulfilled our inclusion criteria. ${ }^{[13-19]}$

Based on the literature data, these patients were usually admitted to urology or gynecology outpatient clinics for various symptoms such as dyspareunia, discomfort during sexual intercourse, and dysuria due to bladder outlet compression. ${ }^{[14-19]}$ In certain cases, it was misdiagnosed with a prostatic mass or prostatic calcification. ${ }^{[13]}$ 
Similarly, in our case, the symptoms were consistent with the literature data and the patient was misdiagnosed with a urinary tract infection.

With respect to the osteochondromas with fibular head involvement, we searched the literature for fibular head originating from osteochondromas which cause peroneal nerve compression, tibiofibular synostosis, and vascular problems due to compression of popliteal vessels and found 14 relevant articles. ${ }^{[20-33]}$

After retrieval from the literature, we observed that the symptomatology was mostly related with peroneal nerve compression except the popliteal artery-related problems.

In our cases, the mass tends to grow towards popliteal fossa, but also laterally adjacent to peroneal nerve (case 3) and compressed the tibial nerve and established a proximal tibiofibular synostosis (case 7). They caused pain in legs; therefore, we scheduled surgery. The case 7 will be the third case in the literature in whom the proximal tibiofibular synostosis features were established.

Clavicular medial-sided osteochondromas and the first rib osteochondromas are anatomically located extremely close to the vascular structures, brachial plexus, and pleura. As a result, osteochondromas in that region may produce much more serious clinical problems such as stroke (carotid artery compression), ${ }^{[34]}$ brachial plexopathy, ${ }^{[35]}$ subclavian vein thrombosis, ${ }^{[36]}$ thoracic outlet syndrome (subclavian artery compression) $)^{[36,37]}$ Horner syndrome, ${ }^{[38]}$ spontaneous hemothorax (as a result of chronic irritation of pleural vessels and mechanical compression) $)^{[39]}$ and venous thoracic outlet syndrome. ${ }^{[40]}$ These locations (clavicula medial side and the first rib) may also cause aesthetic problems and impair shoulder mechanics as well. ${ }^{[11,42]}$

In our case (the first rib-located osteochondroma), the patient was referred to a gastroenterologist with cholangitis-like symptoms. On physical examination, a subclavian lymph node-like mass was detected and the patient was suspected with pathologic lymphadenopathy. In routine radiological studies, the physician incidentally realized that this was actually a bony mass and referred the patient to us for consultation (orthopaedics department). Radiological studies revealed compression on subclavian artery; however, the patient had no discomfort on the right upper extremity. After we informed the patient about the risks of this condition, the patient was scheduled for follow-up. One case reported in the literature had pseudoarthrosis between the clavicle and the first rib which impaired the shoulder biomechanics and caused shoulder pain.

Moreover, clavicular lateral-sided osteochondromas are located adjacent to the rotator cuff muscle tendons and coracoid. They may produce impingement symptoms, if they grow towards coracoid and establish a contact with coracoid process. Consequently, they may impair the mechanics of shoulder joint and cause a painful shoulder arch of motion. ${ }^{[43-48]}$

Similarly, in our case (clavicular origin), the osteochondroma was located at the lateral end of clavicle and the bony mass grew towards coracoid and established contact with coracoid process. Over time, coracoid made a footprint on the bony mass and tumor base shape was changed into a saddlelike appearance (Figure 3). This contact with coracoid probably impaired the shoulder biomechanics, which resulted in shoulder pain and a limited arch of motion.

According to our reported case spectrum and published reports, the most dangerous locations were clavicle and the first rib.

In addition, only 20 articles fulfilled our study criteria regarding scapular involvement. In this area, the symptomatology varies from pseudowinging, snapping scapula, large bursa formation to thoracic deformity. In these 20 articles, some reported surgical techniques. ${ }^{[48-62]}$

Similarly, our patient also had snapping scapula and pseudo-winging symptoms. However, perioperative images and radiological studies were demonstrative and didactic.

\section{Conclusion}

Based on our experience the flat bones, which are usually ossified by intramembranous type of ossification during the fetal period (including the scapula, ilium, pubic ramus, ischium ramus, ribs, and clavicle) are much less commonly affected and often have unusual symptoms, as in our cases presented. The osteochondromas originating from fibular head caused proximal tibiofibular synostosis and tibial and peroneal nerve compression in our case series. The osteochondroma originating from the distal clavicle caused pseudoarthrosis between coracoid and clavicle. The osteochondromas originating from fibular head may seem innocent to an orthopedic surgeon. However, an orthopedic surgeon should be alert to tibiofibular synostosis and nerve compression in this patient population. 


\section{Acknowledgement}

The authors would like to thank Antalya Memorial Hospital chief of medicine Dr Sevim Suekinci for providing the necessary settings for the study and to our English editor Taylan Alpaslan for his work. The junior authors also would like to thank our senior author Ahmet Turan Aydin for his devoted personality and leadership.

\section{Declaration of conflicting interests}

The authors declared no conflicts of interest with respect to the authorship and/or publication of this article.

\section{Funding}

The authors received no financial support for the research and/or authorship of this article.

\section{REFERENCES}

1. Dahlin DC, editor. General aspects and data on 8542 cases. 4th ed. Springfield: Charles C Thomas Pub Ltd; 1986.

2. Greenspan A, Jundt G, Remagen W, editors. Differential diagnosis in orthopaedic oncology. 2nd ed. Philadelphia: Lippincot \& Williams; 2006.

3. Atik OS, Sarikaya B, Kunat C, Muradi R, Ocaktan B, Topçu $\mathrm{H}$. Osteochondroma of the talus. Eklem Hastalik Cerrahisi 2010;21:116-7.

4 Campanacci M. Exostosis. In: Enneking WF, editor. Bone and soft tissue tumors: clinical features, imaging, pathology and treatment. Padova: Springer-Verlag; 1998. p. 179-96.

5. Gökkuş K, Aydın AT, Sağtaş E. Solitary osteochondroma of ischial ramus causing sciatic nerve compression. Eklem Hastalik Cerrahisi 2013;24:49-52.

6. Available from: http://tumorarchive.ior.it/node/82 [Accessed in 1996]

7. D'Ambrosia R, Ferguson AB Jr. The formation of osteochondroma by epiphyseal cartilage transplantation. Clin Orthop Relat Res 1968;61:103-15.

8. Milgram JW. The origins of osteochondromas and enchondromas. A histopathologic study. Clin Orthop Relat Res 1983;174:264-84.

9. Schajowicz F. Cartilage-forming tumors. In: Tumors and Tumorlike Lesions of Bone. Pathology, Radiology, and Treatment. 2nd ed. New York: Springer; 1994. p. 141-256.

10. Schiller AL. Diagnosis of borderline cartilage lesions of bone. Semin Diagn Pathol 1985;2:42-62.

11. Simon RS. Orthopaedic Basic Science. Illinois: Amer Academy of Orthopaedic; 1994.

12. Available from: https://www.boundless.com/ biology/textbooks/boundless-biology-textbook/themusculoskeletal-system-38/bone-216/intramembranousossification-817-12060/

13. Amis ES Jr, Petruzzo RT Jr. Retropubic osteochondroma simulating prostatic calcifications: a case report. J Urol 1980;124:744-5.

14. Iwata S, Ida M, Tokunaga S. Dysuria caused by pressure of osteochondroma. Iryo 1965;19:1110-3. [Abstract]

15. Hoshimoto K, Mitsuya K, Ohkura T. Osteochondroma of the pubic symphysis associated with sexual disturbance.
Gynecol Obstet Invest 2000;50:70-2.

16. Carpintero P, Urbano D, Segura M, de Tembleque FR, Saceda JL. Discomfort during sexual intercourse secondary to osteochondroma: a report of two cases. Joint Bone Spine 2007;74:401-3.

17. Wang WY, Du LD, Lv WC, Tian Y, Shao Q, Zhang YH. Osteochondroma of the symphysis pubis: a rare cause of bladder outlet obstruction. Am Surg 2010;76:916-8.

18. Smith AL, Khan F. Dyspareunia due to osteochondroma of the pubic ramus. J Obstet Gynaecol 1998;18:90.

19. Mnif H, Zrig M, Koubaa M, Zammel N, Abid A. An unusual complication of pubic exostosis. Orthop Traumatol Surg Res 2009;95:151-3.

20. Holzapfel BM, Seppel G, Wagner R, Kenn W, Meffert R. Popliteal entrapment syndrome caused by fibular osteochondroma. Ann Vasc Surg 2011;25:982.5-10.

21. Ballaro A, Fox AD, Collin J. Rupture of a popliteal artery pseudo-aneurysm secondary to a fibular osteochondroma. Eur J Vasc Endovasc Surg 1997;14:151-2.

22. Manoharan A, SUresh SS, Sankaranarayanan. Proximal Fibular Osteochondroma Producing Common Peroneal Nerve Palsy in a Post-Cesarean Section Patient. Oman Med J 2013 May; 28(3). Available from: http://www.omjournal. org/fultext_PDF.aspx?DetailsID=389\&type=fultext

23. Çınar A, Yumrukçal F, Salduz A, Dirik Y, Eralp L. A rare cause of 'drop foot' in the pediatric age group: Proximal fibular osteochondroma a report of 5 cases. Int J Surg Case Rep 2014;5:1068-71.

24. Mnif H, Koubaa M, Zrig M, Zammel N, Abid A. Peroneal nerve palsy resulting from fibular head osteochondroma. Orthopedics 2009;32:528.

25. Cardelia JM, Dormans JP, Drummond DS, Davidson RS, Duhaime C, Sutton L. Proximal fibular osteochondroma with associated peroneal nerve palsy: a review of six cases. J Pediatr Orthop 1995;15:574-7.

26. Wakayama T, Imanishi J, Yazawa Y, Okubo T, Kaneko K. Bilateral non-osteochondroma-related proximal tibiofibular synostosis. Skeletal Radiol 2014;43:1737-42.

27. Paprottka FJ, Machens HG, Lohmeyer JA. Partially irreversible paresis of the deep peroneal nerve caused by osteocartilaginous exostosis of the fibula without affecting the tibialis anterior muscle. J Plast Reconstr Aesthet Surg 2012;65:223-5.

28. Abdel MP, Papagelopoulos PJ, Morrey ME, Wenger DE, Rose PS, Sim FH. Surgical management of 121 benign proximal fibula tumors. Clin Orthop Relat Res 2010;468:3056-62.

29. Yoo JH, Min KD, Kim CK, Cha JG. A case of extension loss of great toe due to peroneal nerve compression by an osteochondroma of the proximal fibula. Arch Orthop Trauma Surg 2010;130:1071-5.

30. Gray KV, Robinson J, Bernstein RM, Otsuka NY. Splitting of the common peroneal nerve by an osteochondroma: two case reports. J Pediatr Orthop B 2004;13:281-3.

31. Bozkurt M, Doğan M, Turanli S. Osteochondroma leading to proximal tibiofibular synostosis as a cause of persistent ankle pain and lateral knee pain: a case report. Knee Surg Sports Traumatol Arthrosc 2004;12:152-4.

32. Hazmy W. Peroneal nerve palsy secondary to proximal fibular osteochondroma--a case report. Med J Malaysia 2001;56:89-90. 
33. Dubost C, Celerier M, Brumpt B, Catinat J, Kaswin R. Compression of the popliteal artery by osteochondroma of the head of the fibula. J Chir (Paris) 1973;105:433-40. [Abstract]

34. Gouicem D, Palcau L, Hello CL, Coffin O, Maiza D, Berger L. Gigantic clavicle osteochondroma with carotid compression as a rare cause of stroke. J Vasc Surg 2013;57:845-7.

35. Mollano AV, Hagy ML, Jones KB, Buckwalter JA. Unusual osteochondroma of the medial part of the clavicle causing subclavian vein thrombosis and brachial plexopathy. A case report. J Bone Joint Surg Am 2004;86:2747-50.

36. Cusson DL, King AB. Osteochondroma involving the first rib with neurovascular compression. Bull Johns Hopkins Hosp 1961;108:157-60.

37. Rosset P, Martinat H, Barsotti J, Gaisne E. Osteogenic exostosis of the first rib: a rare etiology of thoracic outlet syndrome. Apropos of a case. Rev Chir Orthop Reparatrice Appar Mot 1990;76:62-5. [Abstract]

38. Simpson JF. Horner's syndrome due to an osteochondroma of the first rib. Can Med Assoc J 1948;59:152-5.

39. Uchida K, Kurihara Y, Sekiguchi S, Doi Y, Matsuda K, Miyanaga $\mathrm{M}$, et al. Spontaneous haemothorax caused by costal exostosis. Eur Respir J 1997;10:735-6.

40. O'Brien PJ, Ramasunder S, Cox MW. Venous thoracic outlet syndrome secondary to first rib osteochondroma in a pediatric patient. J Vasc Surg 2011;53:811-3.

41. Cain PR, Fu FH. Osteochondroma of the first rib with pseudarthrosis with the clavicle: a rare cause for shoulder pain: a case report. Orthopedics 1984;7:874-6.

42. Aithal VK, Bhaskaranand K. Osteochondroma of the first rib presenting as a prominent clavicle. A report of 2 cases. Int Orthop 1999;23:66-7.

43. Kontakis GM, Karantanas AH, Pasku D, Alpantaki K, Katonis P, Hadjipavlou AG. Delayed diagnosis of a symptomatic osteochondroma of the distal clavicle. Orthopedics 2006;29:734-6.

44. Reichmister J, Reeder JD, Gold DL. Osteochondroma of the distal clavicle: an unusual cause of rotator cuff impingement. Am J Orthop (Belle Mead NJ) 2000;29:807-9.

45. Ogawa K, Yoshida A, Ui M. Symptomatic osteochondroma of the clavicle. A report of two cases. J Bone Joint Surg Am 1999;81:404-8.

46. Fallon PJ, Hollinshead RM. Solitary osteochondroma of the distal clavicle causing a full-thickness rotator cuff tear. J Shoulder Elbow Surg 1994;3:266-9.

47. Vander Maren C, Guillaumie B, Huge J, Bodart A, Van Ruyssevelt C. Osteochondroma of the clavicle and pain syndrome of the shoulder. Apropos of a case. Review of the literature. Rev Chir Orthop Reparatrice Appar Mot 1994;80:334-7. [Abstract]

48. Alman BA, Goldberg MJ. Solitary osteochondroma of the clavicle. J Pediatr Orthop 1991;11:181-3.

49. Ermiş MN, Aykut US, Durakbaşa MO, Ozel MS, Bozkuş FS, Karakaş ES. Snapping scapula syndrome caused by subscapular osteochondroma. Eklem Hastalik Cerrahisi 2012;23:40-3.

50. Tomo H, Ito $\mathrm{Y}$, Aono M, Takaoka K. Chest wall deformity associated with osteochondroma of the scapula: a case report and review of the literature. J Shoulder Elbow Surg 2005;14:103-6.

51. Esenkaya I. Pseudowinging of the scapula due to subscapular osteochondroma. Orthopedics 2005;28:171-2.

52. Orth P, Anagnostakos K, Fritsch E, Kohn D, Madry H. Static winging of the scapula caused by osteochondroma in adults: a case series. J Med Case Rep 2012;6:363.

53. Kwon OS, Kelly JI. Delayed presentation of osteochondroma on the ventral surface of the scapula. Int J Shoulder Surg 2012;6:61-3.

54. Fukunaga S, Futani H, Yoshiya S. Endoscopically assisted resection of a scapular osteochondroma causing snapping scapula syndrome. World J Surg Oncol 2007;5:37.

55. Mohsen MS, Moosa NK, Kumar P. Osteochondroma of the scapula associated with winging and large bursa formation. Med Princ Pract 2006;15:387-90.

56. Chillemi C, Franceschini V, Ippolito G, Pasquali R, Diotallevi R, Petrozza V, et al. Osteochondroma as a cause of scapular winging in an adolescent: a case report and review of the literature. J Med Case Rep 2013;7:220.

57. Shackcloth MJ, Page RD. Scapular osteochondroma with reactive bursitis presenting as a chest wall tumour. Eur J Cardiothorac Surg 2000;18:495-6.

58. Cuomo F, Blank K, Zuckerman JD, Present DA. Scapular osteochondroma presenting with exostosis bursata. Bull Hosp Jt Dis 1993;52:55-8.

59. Frost NL, Parada SA, Manoso MW, Arrington E, Benfanti P. Scapular osteochondromas treated with surgical excision. Orthopedics 2010;33:804.

60. Kumar C Y, Shervegar S, Gadi D, P R. Solitary sessile osteochondroma of scapula, a rare case report. J Clin Diagn Res 2014;8:174-5.

61. Vaishya R, Dhakal S, Vaish A. A solitary osteochondroma of the scapula. BMJ Case Rep 2014 Feb 21;2014. pii: bcr2013202273.

62. Sivananda P, Rao BK, Kumar PV, Ram GS. Osteochondroma of the ventral scapula causing scapular static winging and secondary rib erosion. J Clin Diagn Res 2014;8:3-5. 